\title{
Novel "Moskva-kva-kva" by V. Aksyonov in the Paradigm of Russian Religious Philosophy
}

\author{
Tatiana A. Zagidulina* \\ Krasnoyarsk State Pedagogical University \\ named after V.P. Astafyev \\ 89 Ada Lebedeva Str., Krasnoyarsk, 660049, Russia
}

Received 10.01.2017, received in revised form 02.03.2018, accepted 13.03.2018

This article is devoted to analysis of philosophy underlying the figurative and narrative structure of the novel "Moskva-kva-kva" by V. Aksyonov. This piece belongs to the latest stage of the writer's creative evolution, which means a certain structure of the text, designed in the socio-historical and philosophical discourse, specific for this period. Since the modernist aesthetic dominant prevails in the novel, and Russian modernism is mostly guided by the Russian religious philosophy, it is rational to consider the text within the same paradigm.

The subject of study is the representation and functioning of Sophian features in the main character of the novel, Glykeria Novotkannaya. This research studies the Sophiological motives of "Moskvakva-kva", their functioning in the context of post-apocalyptic emptiness presented by the text. The article reveals the main components of Glyka's image: duality, ethereality, features of the Virgin; it shows the image embedded into the scenically syncretic novel structure, functioning in various mythological patterns the text is based on. The author arrives at the conclusion, that in the narrative, expressive and figurative, mystical aspects, the writer sees no way for Russia to escape from the postapocalyptic emptiness, impossible to fill with anything, ever. The impossibility of the Messiah function to be performed in Russia, the impossibility of it to become a utopia that came true is explained by the return of Sophia-Glyka to her origin.

Keywords: Sofia, Sophiological motives, gnosticism, myth, socialist realism, utopia.

DOI: 10.17516/1997-1370-0244.

Research area: philology.

The novel "Moskva-kva-kva" by Vasily Aksyonov was written in the year 2005. It reflects the tendency for destruction of the traditional novel structure. "Moskva-kva-kva" unites the features of an adventure story, utopia, anti-utopia, and alternative history; it brings the socio-political and philosophic discourses together. Some researchers see this text as a final result of the writer's creative evolution, as a "new novel" that emerged together with "Cesarean", "Voltairian Men and Women" and "Rare Earths" (Chernyshenko, 2007). A "new novel" assumes alternative, non-traditional techniques of writing, constructing text from various cultural codes, which is considered to be the authentic way of reconstructing reality. It is typical for the books

(C) Siberian Federal University. All rights reserved

* Corresponding author E-mail address: zagi9@rambler.ru 
by V. Aksyonov written in that period. It is the presence of numerous cultural codes that makes it possible to research the text from the point of view of its cultural "structure". Keeping in mind that the text has a prevailing modernist aesthetic dominant (determined by the syncretism of genres, neo-mythologism, semiotization of reality, special role of the onlooker), it would be relevant to analyse it on the basis of Russian modernist ideas, including those based on the theories of N. Berdiaev, S.N. Bulgakov, and P.A. Florenskiy (Slobodeniuk, 1998).

We wish to demonstrate the way the ideas of Russian religious philosophy deflect within the novel, and what ways to escape from the Soviet post-apocalypse the author sees. The text may be formally divided into two parts: the events taking place in 1952-1953, and the last chapter, "Forty two years after", acting as an epilogue.

In contemporary literary criticism, there are several interpretations of the novel: (Koliadich, T.M. (Koliadich, 2013), Polupanova, A.V. (Polupanova, 2009), Suvorova, I.V. (Suvorova, 2013), Khanov, B.A. (Khanov, 2013). The mythopoetic interpretation of the text is of greatest interest. Koliadich, T.M., outlines the cosmogonic, heroic, astral and auteur myths (Koliadich, 2013: 81) that form the basis of the novel. It is not a certain myth the researcher focuses on; in the centre of her attention, there is a so-called "neo-myth", "when the space of a single text unites the myth systems of different periods and nations (sometimes, in a random manner)" (Koliadich, 2013: 86). T.M. Koliadich believes that the myth plays the plot-constructing role in the novel.

In his article "Soviet Discourse as the Imperial "Imaginary" in the Novel "Moskvakva-kva" by V. Aksyonov", analysing the text, on one hand, in the aspect of mythopoetics, and through the correlation between the utopic and the imperial, V.A. Khanov arrives at the conclusion that the "Neo-Plato City" image is inconsistent here, and Aksyonov himself proves this inconsistency through the selected mythological code (Khanov, 2013).

V. Aksyonov builds up his texts using several mythological systems: the ancient myth (the myth of Theseus and the Minotaur, Plato's myth of a perfect state (the base of the utopic discourse), and the social-realist myth of the great family described by K. Klark (Klark, 1992). The text also actualizes the Silver age cultural reflection on the gnostic myth, manifested through numerous references to A. Blok and V. Solovyev.

In the text, the myth of the large Stalinist family is naturally combined with the gnostic myth: the socio-realistic father and sons are highlighted with the image of the Trinity (Kovtun, 2004). However, there is a symbolic difference: Sophia, the world soul, comparable to the image of the protagonist, Glyka, does not fit in the big family structure (potentially, it may fit as mother archetype, but the mother motive does not enter the mythical context), it remains alien.

Another approach to studying the novel is researching the text from the utopic and antiutopic points of view. This is the subject of the article titled "Anti-Utopic Stories of Moscow" by A.N. Vorobyova (Vorobyova, 2008). The attention to architecture (description of high-rises, the topos of a constructed house with Stalin's secret shelter on top) suggests that the text is a utopic story, borne from the traditional topic of a perfect city. Numerous Plato's ideas and contemplation on the way they are implemented in the 50 -s, contemporary to the book characters, the created illusion of a rational state where the hierarchy is based on the principle of involvement into creating it, make up the utopia that is gradually demolished in the text.

The main action of the novel unwinds in the early 1950-s, in the Stalin age Moscow. The events encompass the period of nearly one year, 
but flashbacks to the 1920 -s, $30-$ s, or 40 -s are common. The plot is centred around Glykeria Novotkannaya, "the perfect Virgin of Socialism". Glyka is a journalism student at Moscow State University, lives on the $18^{\text {th }}$ floor of the highrise apartment building on Kotelnicheskaya embankment, dreams of being a vestal virgin in the temple of Stalin, when he dies and becomes a god. Her mother, Ariadna Ruerich, is a former Soviet intelligence officer, currently Doctor of Arts, member of the Soviet Peace Committee, Soviet Women Committee and the Committee for Stalin Awards Committee of the USSR. Her father, Ksavery Ksaveryevich Novotkanny, is an academician, a secret nuclear physicist.

Glyka herself finds herself in the centre of a new (future) cult: she is supposed to become the "Mother of the New Phase", the beginning of the world, to fill the post-apocalyptic emptiness with herself. Even though the text presents the image of Stalin (canonical Father), he is not in the centre of the New Phase idea. The Leader is an observer in the periphery of the story. This is why Glyka is in the centre. Her image correlates with that of Blok's Fair Lady (Eternal Femininity as the central idea of Russian philosophy of the early $20^{\text {th }}$ century), that associates her with the gnostic myth of Sophia. Sophian features are found in many heroines of Russian literature. As Kovtun N.V. remarks in her article "Sophiological Paradigm in Books by T. Tolstaya (based on short story 'Sonya')" (Kovtun, 2009: 90): "The image of a perfect, sublime girl, commonly named Sophia, is typical for the dramaturgy of the Enlightenment" (Kovtun, 2009: 90). Such nomination opens an additional mystical dimension of the narration" (Kovtun, 2009: 90), and this image is still relevant in Modernism.

The text of "Moskva-kva-kva" (2005) is a reflection of several cultural ages: Silver Age, Social Realism, prose of the "sixtiers". The image of Glyka is multifaceted, allusively connected to each of these codes, but the Sophian traits prevail.

The present article studies the functional peculiarities of the Sophian motives. Within this paradigm, "Moskva-kva-kva" may be productively correlated to the novel by A. Platonov. Khanov, B.A. describes the connection of the text by V. Aksyonov with "Happy Moscow". The researcher explains the structural similarity of the text with some really close episodes: defloration of Glyka in the air followed by the change of her ontological status, the change in the function of Moscow after the lifechanging parachute jump (subversion, downfall); unification of the heroine's name with the name of the city; unwinding the ideological image of the capital city through the heroine's relations with her beloved ones (Glyka - Mokkinaki Smelchakov - Stalin and Moscow - Sartorius Sambikin - Bozhko) (Khanov, 2013: 116).

The title of the novel, "Moskva-kva-kva", is a reference to Platonov's "Happy Moscow”, where the main character is named Moscow Ivanovna Chestnova (the name coincides with the toponym). In the novel by V. Aksyonov, the name Glykeria is not directly associated with the toponym, but it matches its shortened, playful version: "I like it here in your Kva-Kva" (Aksyonov, 2015: 444) - "kva-kva". Mother lovingly calls her daughter Glyka "Glikushenka, my baby frog" (in Russian: Glikushenka rhymes with lyagushenka) (Aksyonov, 2015: 44). The nomination pattern itself is a reference to Platonov. In both cases, the heroine is equalled to the city which is the capital, the centre of Russia (USSR). Along with that, Moskva-kva-kva and Glikushenka the frog are the explicit embodiments of the city and the girl as chthonic creatures, beasts from the underworld. Its underworld nature is especially distinctive after Glyka's downfall and her defloration. The city is the picture of feminine: "the first woman is still Moskva-kva-kva" (Aksyonov, 2015: 225), 
but it is the deflated feminine: not "lady", but "woman".

According to B. Groys, "for a Russian thinker, a woman is a delusional symbolization of Russia: it evokes, and simultaneously distracts erotic energy to herself" (Groys, 1993: 247). B. Groys equals the "being Russian" and femininity of an intelligent (an intelligent is androgenic), re-coding the discourse of Russia into a quasi-erotic one. But N. Drubek-Mayer associates the interpretation of Russia and its equation to a woman, presented by B. Groys, with Russian religious and philosophic doctrines of the $19^{\text {th }}$ century, where the Sophianity is postulated as one of the most relevant guises of the unconscious (Drubek-Mayer, 1994: 252). The research of "Happy Moscow" is built on the Sophian theory, by indicating the nature of Moscow (Chestnova) as Sophian. It would be productive to study "Moskva-kva-kva" novel from the point of view of symbolizing Russia as a woman-Glyka-Sophia.

In the novel "Moskva-kva-kva", the crisis of the feminine unconscious is manifested through the contemplations of Stalin, the father of the utopic 50-s: "Why don't I see any women's faces? < .. > Can't they replace all those Jews like Kaganovich? <..> Obviously, those bastards regard women only as a resource for a new generation of soldiers $\langle\ldots>$ craving for nothing but satisfaction of their hypertrophic lust" (Aksyonov, 2015: 343), which make Stalin grieve; he is paralyzed with fear, and finally the broken harmony leads to the downfall of the Father.

On the story and expressive levels of the novel "Moskva-kva-kva", the protagonist bears some Sophian features. The deconstructed Stalin's Sophianity, described by N. DrubekMayer, implies a perfect Komsomol girl, keen on socialistic labour (in the novel, Ariadna Ruerich is concerned of bringing her daughter to the idea "of the comprehensive and inspiring power of Productive Labour" (Aksyonov, 2015: 11). In "Happy Moscow", the "graceful Komsomol girl" immerses into the underworld, the Moscow underground tunnels; in the novel by V. Aksyonov, Glyka, on the opposite, "goes out into space" (literally, from the window of the shelter-tower), retaining her pneumatic nature throughout the story.

Glyka is not a human in the full sense of the word; she is presented as a different creature, an unknowable entity: "this spoiled creature is suffering in its wondrous body" (Aksyonov, 2015: 56), "the perfect essence of her generation" (Aksyonov, 2015: 12). The body of Glyka is separate from the "essence", i.e. the essence of Glyka is captured in the "wondrous" body; probably, this division of body from Glyka herself is intended to express the duality of Sophia (lower and upper Sophia in the gnostic myth, the Virgin and the Whore, celestial and mundane).

The generic essence of Glyka is not clear; she was not born, i.e. created. Of her mother, Smelchakov says: "She has always had a daughter, even on her first year of college" (Aksyonov, 2015: 41). Sophia is uncreated too: "She grew up not into a woman, but into a picture of virginity" (Aksyonov, 2015: 45). Along with that, the text clearly points to the parents of Glyka, characterizing her as a being, created by them. This is the manifestation of her Sophian duality. The pneumatic essence of Glyka is expressed through language: "she flutters out from the enormous ZIS-110" (Aksyonov, 2015: 12), "she imagines herself to be $<\ldots>$ the soaring Virgin of Socialism" (Aksyonov, 2015: 13).

The gnostic myth draws a parallel between Sophia and the Ancient Egyptian Isis. Glyka possesses some of her portrait features: "Comrades! / I like one of those / Komsomol girls! / Her body is / All emerald!" (Aksyonov, 2015: 180), "she slapped me with her genuinely emerald laugh" (Aksyonov, 2015: 180). In Ancient 
Egypt, emerald was a symbol of Isis, who, in her turn, was an embodiment of Sophia, the soul of the world. Isis and Sophia are usually syncretic, but the poem by V. Solovyov brings these images together: "It is not Isis with three crowns / Who brings that spring to them, / But the eternal and untouched / Virgin of the Rainbow Gate" (Solovyov, 1994: 402), implying the duality of Sophia. The Rainbow Gate topos is symbolically presented in the novel as a "high voltage arc" (Aksyonog, 2015: 184). Glyka notices that mentioning a high voltage arc is inappropriate, and later she finds out that the performer of the song has been fired from MosConcert for ideological ambiguity.

P.A. Florensky describes Sophia as follows: “... an angel-like figure wearing a royal dalmatic, with shoulder-mantles and an omophorion. Her long hair does not curl, streaming down her shoulders. Her face and hands are of the colour of flame, there are two large fiery wings behind her back, a gold caduceus on her head; her left hand is holding a closed phylactery, pressing it against her heart; around her head, there is a gold halo, and ribbons over her ears" (Florensky, 1990: 372). The heroine has an angel nature: "the angel of socialism" (Aksyonov, 2015: 47), "gold hair in a heavy braid, long neck, ducky collar bones" (Aksyonov, 2015: 47). Glyka is constantly "blushing" and her eyes "light up with incredible fire": "the girl's looks behind the shoulder, as well as the frequently changing golden halo have begun to torture her experienced bridegroom quite a lot" (Aksyonov, 2015: 61). Sophia is always surrounded with fire. Even in the painting by N. Roerich (obviously, word play with the last name of Glyka's mother, Ruerich) "Sophia - The Wisdom the Almighty" is flying across the sky on a fiery horse in a cloud of fire, and looks as though she is made of fire herself.

One of the incarnations of Sophia is the Holy Virgin (Florensky, 1990). The image of the protagonist is associated with her both on the narrative and the expressive levels. Glyka is wearing a "marquisette cornflower blue dress", and in Christianity blue colour symbolizes the Holy Virgin, spirituality, and mystery, which matches the Sophian features of the protagonist. At the end of the novel, before vanishing into thin air, "Glyka, dressed in a gorgeous blue dress with a bell-shaped skirt and a yellow puffed top, but barefoot" (Aksyonov, 2015: 420), appears before her mother to express her wish to ascend to the Leader. Yellow and blue are traditional colours of the Holy Virgin.

On the narrative level, the Holy Virgin features are expressed through the fact that Glyka is supposed to become "the mother of the New Phase", but the "New Phase" is never born: this line remains incomplete, the supposed birth ends with the death of the mother vanishing into thin air, and symbolic return to the beginning. Repetition of Sophia as a Virgin and a Whore is actualized through the Valentinean gnostic tradition, as Sophia is divided into the higher and lower.

According to P.A. Florensky, Sophia is "an intangible state of transition between God and its creature" (Florensky, 1990: 360), she is soaring on the borderline between the divine energy and mundane passiveness. The ambiguity of Sophia is also presented in the pages of the novel; it manifests itself through the image of Glyka: Glyka and the "heavenly bride" of Smelchakov, and the mistress of Mokkinaki. She is pure and sinful at the same time (not throughout the novel; at different stages of the story, her ontological status changes, but the ambiguity remains). According to S. Bulgakov, Sophia is a "third being", neither God nor belonging to the world. Bulgakov spoke of two faces of Sophia: celestial (divine) and earthly (mundane).

The novel consists of parts, different in their aesthetic dominants: utopic (with inclusions 
of alternative history motives) and realistic. The end of the utopia (transformation of utopia into anti-utopia) is marked with the downfall of Stalin's Sophia, Glyka. The author pays special attention to the virginity of his heroine. "The basic condition of the erring Sophia, prior to its differentiation into a plurality of affections, is ignorance" (Jonas, 2007). Ignorance here may be interpreted as innocence, absence of knowledge. "But the Holy Ghost shows Itself in a creature as chastity, as inner innocence and humble purity, in these gifts a Christian may receive from Him. In this sense, Sophia means Chastity, as heavenly power granting virginity" (Florensky, 1990: 350). Defloration of Glyka means her downfall, subversion, but only on the lower, mundane level. At the end of the novel the higher Sophia is actualized, while Glyka leaves her body, it feels too small for her "I feel cramped $<\ldots>$ most of all, I feel so in my own body" (Aksyonov, 2015: 417).

The motive of Glyka's defloration formally coincides with the apocalyptic "Exegesis of the Soul" (a piece from the Nag Hammadi library). When the soul bearing a female name lived at the Father by herself, it was in form androgynous; but having found a female body and having come to earth, it began to "fornicate", though repented later: "And she received the divine nature from the father for her rejuvenation, so that she might be restored to the place where originally she had been. This is the resurrection that is from the dead. This is the ransom from captivity. This is the upward journey of ascent to heaven. This is the way of ascent to the father" (Exegesis). Similarly, Glyka, who has initially wanted to remain a virgin forever to become a vestal virgin in the temple of Stalin after his death, meets Mokkinaki to obtain her genuinely female, mundane essence, to surrender to the sensual and bodily pleasures. First it happens with her earthly bridegroom, George, then with her heavenly one, the union with whom after
Glyka's downfall loses the heavenly features; that is Kirill Smelchakov.

The love affairs of the heroine are not selfworth; they are nothing but a way to reach her Father. "The passion was a search for the Father, for she strove to comprehend his greatness. This, however, she failed to achieve, because what she attempted was impossible, and so she found herself in great agony; $<\ldots>$ into which in her desire she penetrated more and more, she would in the end have been swallowed up by its sweetness and dissolved in the general being, had she not come up against the power that consolidates the All and keeps it off the ineffable Greatness" (Jonas, 2007). In the passionate coition with her lovers, she attempts to cognize her true Father, Stalin: "You know, sometimes before the moment you seem to me like young Joseph Vissarionovich" (Aksyonov, 2015: 401), she says to Smelchakov.

Before defloration of Glyka, the novel is based on the traditional Social Realistic myth of the great family (Father Stalin and his hero sons) with its ideals of puritanism, incarnated in the protagonist. She might also represent the archetype of mother (Gunter, 2000), but she does not become a mother, which is another element of deconstruction of the said mythological system. The utopic character of the 50-s reality is witnessed by its existence on the verbal level: "If someone was not spoken about any more, the talks were never resumed" (Aksyonov, 2015: 66). It means that if one ceased his existence at the verbal level, he ceased existence everywhere (an arrested person was expelled from the everyday life and, simultaneously, from the verbal space). The utopic contemplations of Plato are frequently recalled, and Moscow is referred to as a "NeoPlato City". The author correlates Stalin's Moscow to Plato's utopia: "I am thinking of similarities and differences of people belonging to the two utopias" (Aksyonov, 2015: 171). The utopia of the 50 -s appears as post-apocalyptic in the novel. 
The empty post-apocalyptic world needs to be filled. According to S.N Bulgakov, "Conception of the world in Sophia is the move of the whole Holy Trinity in each of Its Persons encompassing <...> the Eternal Femininity, which becomes the origin of the world" (Bulgakov, 1999: 195). Glykeria Novotkannaya is supposed to become the mother of the new world, that would resurrect in the Soviet postapocalyptic emptiness to fill it. The postapocalyptic perception of the world is also proven by the fact that Kirill Smelchakov calls the "Revolution poem", "Twelve" by Blok, the "poem of Apocalypse". After the change in Glyka's ontological status, utopia turns into anti-utopia, where the social-realistic myth is decomposed and the text is filled with different aesthetic codes: the cap prose, the sixtiers.

The "New Generation" chapter (the action of the chapter takes place before the defloration of Glyka) marks the transition from the utopic description of the "Neo-Plato City" to a realistic dimension; there appear some new characters, directly and plainly associated with that historical period. Those are: Tak Takovsky and Yurka Donderon. The emphases are shifted: in this reality Stalin is no longer a demigod, but a "creep" (Aksyonov, 2015: 121), "cockroach" (Aksyonov, 2015: 312), a chthonian creature. The essence of Glyka also begins to transform: "Glyka Novotkannaya, / A tumultuous one, / Demon body / Angel face / How stunning Glyka is!" (Aksyonov, 2015: 123), is the way Tak Takovsky describes her. The heavenly features of Glyka are not there anymore; so are those of an underworld creature.

Glykeria Novotkannaya happens to be at a fops' party atDonderon's; on the narrative level, the episode associates with the poem "The Stranger" by A. Blok: "All of the them smudged themselves with whatever they could find: Provence oil, lipstick, tomato scraps, sticky cacao-chou liquor, snot-like spits, spit-like wort, wort-like slag, as well as general over-nicety and stuck-up jackjams. It was hard to imagine the unsullied virgin Glykeria in such an environment..." (Aksyonov, 2015: 126). Just like in "The Stranger", the image of the heroine contrasts with the surrounding chaotic and disgusting reality. "The Stranger" was the first sign of the Fair Lady crisis in the poetry of A. Blok; in the novel by Aksyonov, that is when the image of the perfect virgin of socialism begins to fall apart.

Defloration of the main character is one of the key episodes of the novel. Glyka's virginity is taken by George Mokkinaki; at first, George brings Glyka to a restaurant (before that, she has only been to "Nacionalle" with Smelchakov, when both of them bore the status of the heavenly bride and bridegroom); the restaurant environment is marked as forbidden by the author: "in the Soviet habitat, restaurants $\langle\ldots>$ were considered to be $<\ldots>$ the shrines of $\sin ^{\prime \prime}$ (Aksyonov, 2015: 186). Later, he takes her to pseudo Abkhazia. Mokkinaki should be perceived from the point of view of ostensibility, imposture, lies: "the mundane man who dragged me, just dragged me to the sky" (Aksyonov, 2015: 189), "will caress me with his fatherly sight" (Aksyonov, 2015: 189). The coition is described with some incestual motives: "Glyka, my daughter, my wife!" (Aksyonov, 2015: 245), with an obvious reference to the apocryphal "Interpretation of the Soul", where the soul mistakenly calls the adulterers her husbands. The evanescence of mundane marriage engagement is emphasized with the ostensibility of Mokkinaki. Therefore, the author outlines the crisis of Sophianity, the possible loss of Sophia in the utopia dimension.

Besides other attributes, Mokkinaki is described as a monster: "Pasiphae was quite a hetaera. She copulated with monsters. $<\ldots>$ Bloody monster! I love your jug ears!" (Aksyonov, 2015: 201). The demonic nature of Mokkinaki 
manifests itself in the variability of his character, sudden appearance and disappearances: "Having said that, he put the one-million wad of non-cash into his pocket and disappeared" (Aksyonov, 2015: 176). The holiness of the name Georgy is demolished, carnivalized: “Ah, George! You are so strange, just incredible, a carnival guy you are!" (Aksyonov, 2015: 185). This is why the apocryphal motive of Sophia's blessing Georgy for a battle is not actualized in this text.

Glyka states the change in her ontological status herself: "At that moment she was pierced with the thought that she behaved like a prostitute" (Aksyonov, 2015: 173). The heroine feels inclination to colloquial vocabulary: "what other girl may be so lucky: break the cherry at the altitude of five thousand meters, and find such a cool cat like you..." (Aksyonov, 2015: 198). By the way, colloquial expressions are quite frequent in the author's descriptions: “...her winkers wide open...” (Aksyonov, 2015: 182).

Glyka interacts with George the impostor, Smelchakov the poet and Stalin physically, bodily. All of them are one in Glyka, just like the Holy Trinity is one in Sophia: "holding Glyka with all his limbs, he felt her like an embryo inside his own body" (Aksyonov, 2015: 191). "I feel like Glyka is not driving us apart, but bringing us together" (Aksyonov, 2015: 319), says Smelchakov to George. The Son and the Holy Ghost are of the same nature as the Father; Father Stalin is of chthonic nature, and, therefore, his Holy Ghost and Son possess the same attributes.

Mokkinaki, Stalin and Smelchakov act like the Holy Trinity in the novel. In the context of the big family myth, Stalin acts as the Father "harsh, but fatherly opinion of the leader" (Aksyonov, 2015: 231), almost God: "The order of Stalin is the law of nature" (Aksyonov, 2015: 240). Glyka feels that Stalin may become a god, but she "dissolves in the general being" in her attempt to unite with the Father with her passion. Despite the father connotation, Stalin is presented as a chthonic creature.

Mokkinaki is the Son rejected by the Father; after this rejection he obtains some demonic features, he is overthrown (but his demonic nature corresponds to the chthonic status of the Father). The fact that Mokkinaki is the Son, matches the place occupied by Mokkinaki in the socialrealistic code: he is a pilot, he is a saviour (takes part in the Comintern multi-engined aircraft rescue campaign), he is a protector. Just like the Son, he resurrects, but not to ascend to heaven, not to serve as the substitutionary atonement, but to destroy the Father. "I was shot in a Yaroslavl prison, no trial, no record" (Aksyonov, 2015: 251), he says. After his resurrection, George finds some features of a supernatural creature: "his tender hands, his soft lips, his fluffy chest..." (Aksyonov, 2015: 307). The essence of the Father is transferred to Mokkinaki by his "murder" committed by his father: "they succeeded to turn me into a pathetic, trembling creature" (Aksyonov, 2015: 251).

Smelchakov incarnates the Soviet Holy Ghost. Kirill Smelchakov is the Heavenly Bridegroom of Glyka, being, simultaneously, a part of her: the deep sensuality of his poems is numerously emphasized in the novel: "Is it right, Kirill, that you are criticized for... for... for your sensuality?" (Aksyonov, 2015: 51). Sensuality of the poet's love poems is extrapolated on the character himself, becoming his feature and his attribute. Sensuality means, first of all, physicality of Sophia. Glyka requests Kirill to become "something like the eternal bridegroom of an eternal maid". The "eternal bridegroomhood" is profaned with the physical coition of the couple. But despite his seeming loyalty to the Father, Smelchakov is thinking of his death: "smoking frankincense for him, surreptitiously I wish he was dead" (Aksyonov, 2015: 312). 
After an act of oral sex, Smelchakov cites his new poem to Glyka: "Ah, my dear girl, / I remember you walking to the red day sounds / Beaming and sobbing, / Carrying a portrait of Stalin" (Aksyonov, 2015: 178). It makes Glyka think: "This is what you need to do to become someone's persona" (Aksyonov, 2015: 176). It is the physical coition with a man of words that turns her into a persona, incarnating her in a form of text. Being a poet, Kirill symbolizes the logos - the word; even his name - Kirill, meaning the teacher of words - connects him to words, and the Word and the Father God are inseparable from each other. But Kirill is also presented as a creature related to something supernatural: "just like me, he will resurrect in the Bolshevik Walhalla as a new god, as a founder of a new, unknown religion" (Aksyonov, 2015: 341), says Smelchakov about Stalin.

The Northern Christian baptizers have always associated Walhalla with hell, and daily resurrection and battle with hellfire. The Bolshevik Walhalla corresponds to the supernature of the Soviet Trinity. The Soviet state itself appears as a chthonic creature: "there hung a big drawing of a big Soviet Union-shaped cow carcass <... our dragon will be broken down according to that drawing" (Aksyonov, 2015: 263).

The Holy Trinity takes possession of Glyka in a bodily, physical way. The universal soul is perceived erotically by the author; eroticism is highlighted by the motive of incest and lapse from virtue. The death of the novel characters is symbolic: the Social Realistic canon requires that death finds some features of the character, but in the novel death is presented as a transition to the origin, the inverted birth: "He saw Glykeria, sitting in the sky, her legs wide open $<\ldots .>$ 'Here you are, my boys $<\ldots>$ Now go up into me" (Aksyonov, 2015: 438). In the novel, Glykeria Novotkannaya, Kirill Smelchakov, George Mokkinaki and Stalin die. Stalin just disappears after he dies. Kirill, George and Glyka ascend to the sky and leave the underworld.

In the novel by V. Aksyonov, the world of the 50 -s is perceived as a myth; the novel is a reflection of the myth. Introduction of alternative history motives into the story is symptomatic; it is the manifestation of "deliberate interest to the crisis points of the past, contemplated to find the ways of overcoming tragedies of the present" (Kovtun, 2005: 5). But for Aksyonov, it is not a tragedy of the present; it is a tragedy of the future in the past, division of the novel into two formal parts: utopia and reality. Aksyonov creates a version of reality by combining Russian history and gnostic myth, while Aksyonov's Sophia dissolves in the air, returning to her roots, and there is no "new phase" to begin. SophiaGlyka reunites with Mokkinaki the Son and Smelchakov the Holy Ghost in heaven, but in the mundane world she remains only embodied in the Word. It is worthwhile noticing that she does not reunite with all elements of the Holy Trinity. Stalin the Father simply disappears. He dies without any metaphysical background. Therefore, Sophia-Glyka occupies his position in the Trinity. Aksyonov fits the heroine into the text of the present, but this element will only be presented through a word, a sacred word: "Do you remember, miss Gorskaya, a man called Kirill Smelchakov? <..> No, I don’t remember him. $<\ldots>$ But maybe you remember George Mokkinaki? < . > Definitely not. <..> Glyka Novotkannaya? $<\ldots>$ Do not take her name in vain, she is a saint of the New Phase!" (Aksyonov, 2015: 446). Therefore, the space retains its emptiness.

According to V. Aksyonov, as a new religion, socialism cannot become something Russia will preach to the world: "feeding local Abkhazians with the wisdom of sunny Stalinism" (Aksyonov, 2015: 355). Glyka is dreaming of a life together with Mokkinaki and Smelchakov, 
but this is not meant to happen, since all of them will die in Russia (and ascend to the "Heavenly world"). The messiah function of Russia does not seem productive and possible to Aksyonov, just like the intention of Russia to be brought to life as a socialistic utopia. This is where the opinion of V. Aksyonov coincides with the position of A. Platonov: "Neither a mystical soul, nor a communist heaven are hidden within the borders of this empire" (Drubek-Mayer, 1994:
267). Following A. Platonov (Drubek-Mayer, 1994: 267), V. Aksyonov describes Russia with an attribute of post-apocalyptic emptiness, that cannot ever be filled with anything. The female unconscious of the new Moscow of 1995 is presented only through the image of an elderly animal tamer Kristina Gorskaya, who called Glyka a saint. The world soul remains in the word, but it will fade with the death of the one who bears the word.

\section{References}

Aksyonov, V. (2015). Moskva-kva-kva [Moskva-kva-kva]. Moscow, Eksmo, 448 p.

Bulgakov, S.N. (1999). Pervoobraz i obraz: sochineniia $v 2$ tomakh [Prototype and image: collected works in 2 volumes]. Moscow, Iskusstvo, $448 \mathrm{p}$.

Chernyshenko, O.V. (2007). Romany V.P. Aksyonova: zhanrovoe svoeobrazie, problema geroia i osobennosti avtorskoy filosofii: zhanrovoe svoeobrazie, problema geroia i osobennosti avtorskoy filosofii [Novels by V.P. Aksyonov: genre originality of the problem and the particular character of the author's philosophy: the peculiarity of genre, the problem of the hero and the author's particular philosophy]. Rostov-on-Don $181 \mathrm{p}$.

Drubek-Majer, N. (1994). Rossiia - «pustota v kishkakh mira»: «Schastlivaia Moskva» (19321936) A. Platonova kak allegoriia [Russia - "emptiness in the bowels of the world": "Happy Moscow" (1932-1936) by Andrei Platonov as an allegory], In Novoe literaturnoe obozrenie [New Literary Review]. 9, 251-268.

Florensky, P.A. (1990). Stolp i utverzhdenie istiny [The pillar and ground of the truth]. Moscow, Pravda, 490 p.

Groys, B. (1993). Utopiia i obmen. Stil' Stalin. O novom [Utopia and exchange. Style Stalin. On the new]. Moscow, $374 \mathrm{p}$.

Gunter, H. (2000). Arkhetipy sovetskoy kul'tury [Archetypes of Soviet culture], In Sotsrealisticheskiy kanon [Socialist Realism canon]. Saint Petersburg, Akademicheskiy proekt, 743-784.

Khanov, B.A. (2013). Sovetskiy diskurs kak imperskoe "voobrazhaemoe" v romane V. Aksenova "Moskva-kva-kva" [Soviet imperial discourse as imagined in the novel "Moskva-kva-kva" by V. Aksyonov], In Ural'sky filologicheskiy vestnik [Ural Philology Newsletter], 2, 115-126.

Jonas, H. (2007). Gnostitsizm [The Gnostic Religion]. Available at: http://psylib.org.ua/books/ jonas01/ (accessed on November 5, 2016).

Klark, K. (1992). Stalinskiy mif o «Velikoy semye» [Stalinist myth of "Great Family"], In Voprosy literatury [Literature Issues]. 1, 72-95.

Koliadich, T.M (2013). Mifologicheskiy diskurs v romane V. Aksyonova "Moskva-kva-kva" [Mythological discourse in the novel "Moskva-kva-kva" by V. Aksyonov], In Vestnik Viatskogo gosudarsvennogo universiteta [Vyatka State University Newsletter]. 2-2, 81-86.

Kovtun, N.V. (2004). Utopiia sotsrealizma i gnostitsizm. K postanovke problemy [Utopia of Social Realism and Gnosticism. Problem setting], In Evropeyskie issledovaniia v Sibiri: Materialy 
Vserossiyskoy nauch. konf. «Mir i obschestvo v situatsii frontira: problemy identichnosti» [European research in Siberia: Proceedings of the All-Russian Scientific Conference "The world and society in a frontier situation: problems of identity"]. Tomsk, 4, 247-265.

Kovtun, N.V. (2005). Russkaia literaturnaia utopiia vtoroy poloviny XX veka [Russian literary utopia of the second half of the twentieth century]. Tomsk, Tomsk University Press, $452 \mathrm{p}$.

Kovtun, N.V. (2009). Sofiologicheskaia paradigma v tvorchestve T. Tolstoy (na materiale rasskaza «Sonya») [Sophiological paradigm in books by T. Tolstaia (Based on short story “Sonia”)]. In Research Journal for Literary Scholarship, 51(2), 90-99.

Polupanova, A.V. (2009). Transformatsia avtorskogo povestvovania v prose V. Aksyonova (“Skazhi izium" - "Moskva-kva-kva") [Transformation of the author's narration in prose by Aksyonov ("Say Cheese" - "Moskva-kva-kva"], In Vestnik Bashkirskogo univesiteta [Bashkir University Newsletter]. 14, 162-165.

Slobodeniuk, S.L. (1998). «Iduschie putiami Zla». «Dyavoly» «serebrianogo» veka (Drevniy gnostitsizm i russkaia literatura 1890-1930 gg.) ["Running Evil routes." "Devils" of the "Silver" Age (Ancient Gnosticism and Russian literature of 1890-1930]. Saint Petersburg.

Solovyov, V.S. (1994). Stat'i; Stikhotvoreniia i poema; Iz "Tryokh razgovorov": Kratkaia povest' ob antikhriste [Articles; Poetry and poems; From "Three Conversations": A short story of the Antichrist.]. 528 p.

Suvorova, I.V. (2013). Khronotop Moskvy v romane V. Aksyonova "Moskva-kva-kva" [Chronotope of Moscow in "Moskva-kva-kva" by Aksyonov], In Molodoy uchyonyy [Young scientist], 2, 222-224.

Tolkovanie o dushe [Interpretation of the soul]. Available at: http://apokrif.fullweb.ru/nag hammadi/about_soul.shtml (accessed 5 November 2016).

Vorobyova, A.N. (2008). Moskovskie antiutopicheskie siuzhety [Moscow anti-utopian stories], In Izvestia Samarskogo nauchnogo tsentra Rossiyskoy akademii nauk [News of the Samara Scientific Centre of the Russian Academy of Sciences]. 1, 222-224.

\section{Роман В. Аксенова «Москва-ква-ква» в парадигме русской религиозной философии}

Т.А. Загидулина Красноярский государственный педагогический университет им. В.П. Астафьева, Россия, 660049, Красноярск, ул. Ады Лебедевой, 89

Статья посвящена анализу философских оснований образной и сюжетной структуры романа В. Аксенова «Москва-ква-ква». Произведение относится к последнему этапу творческой эволючии писателя, что позволяет говорить о характерном для этого периода конструировании текста в рамках сочиально-исторического и философского дискурсов. В романе преобладает модернистская эстетическая доминанта, а русский модернизм во многом ориентирован на русскую религиозную философию, поэтому текст можно рассматривать в этой парадигме.

Предметом исследования является репрезентация и функиионирование софийных черт в образе главной героини романа - Гликерии Новотканной. В статье рассматриваются софиоло- 
гические мотивы в романе «Москва-ква-ква», их функиионирование в ситуации постапокалиптической пустоты, представленной в тексте. В статье выявлены основнье составляющие образа Глики: двойственность, пневматичность, богородичность, показано, как данный образ встраивается в синкретичную в жанровом смысле структуру романа, как он функиионирует в различных мифологических системах, на основе которых сконструирован текст. $B \mathrm{cma-}$ тье сделан вывод о том, что на сюжетном, образно-выразительном, а также мистическом уровне автор не видит путей выхода России из состояния постапокалиптической пустоты, не способной заполнится ничем и никогда. Невозможность мессианской функции России и невозможность стать воплощенной утопией в данном тексте обосновываются сюжетным возвращением Софии-Глики к первоначалу.

Ключевые слова: София, софиологические мотивы, гностицизм, миф, сочреализм, утопия.

Научная специальность: 10.00.00 - филологические науки. 